\title{
Effect of Management Information System on Quality of Financial Reporting: A Case of the Institute of Accountancy Arusha, Tanzania
}

\author{
Shamsia Ahmed Mansoor* \\ ORCID: 0000-0001-9683-6301 \\ Department of Accounting and Finance \\ Institute of Accountancy Arusha, Tanzania \\ Valensi Kagoro \\ ORCID: 0000-0003-2533-7980 \\ Department of Accounting and Finance \\ Institute of Accountancy Arusha, Tanzania \\ *Corresponding Mail: shamsiamansoor0@gmail.com

\begin{abstract}
Copyright resides with the author(s) in terms of the Creative Commons Attribution CC BY-NC 4.0. The users may copy, distribute, transmit and adapt the work, but must recognize the author(s) and the East African Journal of Management and Business Studies
\end{abstract}

\begin{abstract}
This study sought to establish the relationship between financial management information system and the quality of financial reporting at the Institute of Accountancy Arusha, using the descriptive design. Data was analyzed through descriptive statistics and Pearson Correlation. The study established that the management information system operates well at the Institute as financial statements are prepared based on required standards. As a result, there is a significant positive relationship between the Management Information System and the quality of financial reporting. This means that management information system enhances the quality of financial reporting. The study therefore recommends that the institute should make effort to maintain the effective management information system as such is very important for not only financial reporting but also for other operations in the learning institution.
\end{abstract}

Keywords: Management Information System; quality; financial Reporting

How to cite: Mansoor, S. A, and Kagoro, V. (2021). Effect of Management Information System on Quality of Financial Reporting: A Case of the Institute of Accountancy Arusha, Tanzania. East African Journal of Management and Business Studies 1(1), 16-21. Doi: https://doi.org/10.46606/eajmbs2021v01i01.0003

\section{Introduction}

Quality of financial reporting plays a very significant role in the management success or failure of any entity as it determines the viability of future strategic decisions of the organization (Renkas, Goncharenko and Lukianets, 2015). Therefore, the quality of financial reporting has been a concern to accounting researchers due to existing accounting scandals and financial crises (Amidu, Effah and Abor, 2011). Scandals and financial problems challenge stakeholders' trust concerning the financial reports and raise criticisms about quality of financial reporting (CAG, 2020).Studies show that the manual systems of accounting and financial reporting has many limitations and anomalies that inhibit effectiveness and efficiency in collecting revenue, making payments and preparing quality financial reports (CAG, 2020).

Financial management information system is considered as a tool to help management in planning and controlling processes by providing 
the relevant and reliable information for decision making. Financial management information system is responsible for recording, analyzing monitoring and evaluating the financial condition of organizations and providing information to support many other organizational functions (Amidu et al., 2011). Adoption of management information system in public entities is therefore, an essential key for entities to operate well.

After recognizing the arbitrariness of the manual system, the government of Tanzania was advised to implement different reforms to harmonize accounting and financial management information systems in order to improve the quality of financial reports. Various initiatives were made by the government to improve the situation including establishment of government e-payment gateway system (GePGS), Tanzania Integrated System, Government Payment System (GPS) and Government Assets Management Information System (GAMIS). In 1996, the integrated financial management system was developed by the government as part of the civil service reform program Customized versions of the accounts payable, accounts receivables, general ledger, cash management and purchase order modules were installed for government ministries and now all central government budgetary expenditure is implemented through the system (URT, 1998).

Despite implementation of the foregoing strategies by the government entities to improve quality of financial reports, the financial reports lack qualities as described on financial reports preparation guidelines. Key stakeholders of the government including the parliament and the Controller and Auditor General (United Republic of Tanzania, 2021) have shown their concern with regard to poor accounting and financial reporting of the government entities. Based on the concerns raised on qualities of reports and adoption of IFMS in government institutions, this study aimed to examine the effect financial management information system on the quality of financial reports in Tanzania.

Tanzania is one of many developing countries where multiple E-government initiatives are being introduced to support poverty reduction and sustain good governance. Such initiatives are driven by the promise of efficiency and transparency in governance to leapfrog the slow process of development and are exemplified by Tanzania's ICT policy, dating back to 2003, where E-government was introduced as a major driving force to enhance sustainable socio-economic development and accelerated poverty reduction both nationally and globally (Management Review, 2006). The National Payment Systems Act was enacted in 2015 to address electronic and mobile transactions in Tanzania (URT, 2016). The act was introduced to reduce risks, bring convenience and reduce transaction costs (Okiro, Aduda \& Omoro, 2015).

Several studies have been conducted in Tanzania on the ICT and e-payment. The studies indicate that problems associated with ICT and e-payment are due to administrative incapacity, inexperienced staffs, corruption and poor plans and policies (Kaongo, 2015). To address the situation, some studies have suggested that ICT and e-payment have an effect on the effectiveness and efficiency in operational performance which increased monthly revenue returns (Mohamed, 2015) reduced administrative and collection costs, and increased transparency (Chatama, 2013).These studies have concentrated on the impacts of ICT and e-payment (EFDs. Limited research has been carried out in the area of financial management information system on quality of financial reports in public entities.

This study was guided by the Technology Acceptance Model which was introduced by Davis (1985) who argues that emerging technologies cannot improve the organizational effectiveness and performance if the change has not been accepted by the users. Therefore, implementation of any innovation, especially information technology, requires investment in computerbased tools to support decision making, planning, and communication. It is therefore very critical that the systems are specified on organizational preference and logic. It is also necessary to recognize that people may resist technological changes. An institution should therefore strive to understand why people resist changes and the possible ways through which the resistance can be resolved (Kamel, et. al. 2014). The use of the management information systems may enhance the quality of financial reporting. This study was guided by the following research questions:

1. To what extent is the Management Information System effective for financial 
reporting at the Institute of Accountancy Arusha?

2. What is the quality of financial reporting at the Institute of Accountancy Arusha?

3. Is there significant relationship between the Management Information System and the quality of financial reporting at the Institute of Accountancy Arusha?

\section{Research Methodology}

According to Mugenda and Mugenda (2003), design relates to a study framework or plan that seeks to discover a suitable alternative for research issues which include hypothesis testing, method and techniques for collecting and analyzing information and results presentation in a manner that can be understood. This study employed the descriptive research design.

\section{Population and Sampling}

According to Kombo and Tromp (2006), population is a group of individuals, objects, or items from which samples are taken for measurement. The population of this study was 306 employees of the Institute of Accountancy Arusha. The study sample was 130 respondents who were selected through simple random sampling and were given a closed ended questionnaire to fill.

\section{Validity and Reliability}

Validity was ensured by three research experts who checked the content of the questionnaire and improved it before it was used for data collection. The Cronbach's alpha coefficient was used to evaluate the reliability of the questionnaire prior to data analysis. The Cronbach's Alpha for each variable was above 0.7 meaning the questionnaire was reliable for data collection.

\section{Statistical Treatment of Data}

The information collected was analysed through both descriptive statistics for the first two research questions and Pearson Correlations for the third research question. The first two research questions were analysed descriptively through mean scores and standard deviations in order to describe the perception of respondents regarding the independent and the dependent variables. The mean score interpretation was as follows: 1.00 to 1.49 indicated strongly disagree, 1.50 to
2.49 denoted disagree, 2.50 to 3.49 denoted agree and 3.50 to 4.00 denoted strongly agree.

\section{Ethical Considerations}

Participation was voluntary and none of respondents was forced to participate. Confidentiality of the data was ensured and permission was sought from relevant authorities before the researchers went to the field for data collection.

\section{Results and Discussion \\ Demographics of Respondents}

The analysis of data started with the presentation of demographics of respondents in order for readers to establish the nature of people who participated in the study by filling the questionnaire. Respondents were categorized according to their gender, whereby 87 (63\%) were males, 45 (32.6\%) were females and 6 (4.3) did not disclose their gender.

Respondents were further categorized according to their working experience where 79 (57.2\%) had the working experience of five years or below, 16 $(11.6 \%)$ had the experience of six to ten years while $31(22.5 \%)$ had the experience of over ten years and $12(8.7 \%)$ did not disclose their working experience. Finally, the level of education was another factor by which respondents were classified where $7 \%$ had primary education, $4.3 \%$ had secondary education, $71.7 \%$ had tertiary education and $5 / 1 \%$ had no formal education; finally, $18.1 \%$ did not disclose their educational level.

Research Question 1: To what extent is the Management Information System effective for financial reporting at the Institute of Accountancy Arusha?

This research question sought to establish views of respondents regarding the Management Information System that is used in the institution as described in table 1 . The table indicates that the overall mean score was 3.0483 with the standard deviation of .41448 . The mean score indicates general agreement with the statements while the standard deviation shows that responses were not scattered but were close to each other. The table further indicates that the mean score for each item was between 2.50 and 3.49 which means they agreed with all the items. 
Table 1: Perceptions on Management Information System

\begin{tabular}{|c|c|c|c|c|}
\hline SN & Management Information System & Mean & Std Dev & Interpretation \\
\hline 1 & The management supports adoption and usage of technology & 3.1250 & .62583 & Agree \\
\hline 2 & There is availability of software and hardware at the working place & 3.1103 & .62861 & Agree \\
\hline 3 & Organizational policy supports usage and adoption of technology & 3.0809 & .65608 & Agree \\
\hline 4 & Management information system supports financial reporting & 3.0803 & .63081 & Agree \\
\hline 5 & Management follows up the adoption and usage of technology & 3.0667 & .56251 & Agree \\
\hline 6 & $\begin{array}{l}\text { The organization provides adequate training about usage of } \\
\text { technology }\end{array}$ & 2.9704 & .63411 & Agree \\
\hline 7 & Infrastructure supports the use of technology in the organization & 2.9191 & .63310 & Agree \\
\hline & Overall Score & 3.0483 & .41448 & Agree \\
\hline
\end{tabular}

Table 2: Perceptions on Quality of Financial Reporting

\begin{tabular}{llccc}
\hline SN & Management Information System & Mean & Std Dev & Interpretation \\
\hline 1 & $\begin{array}{l}\text { Financial reports are relevant, comparable and reliable for } \\
\text { decisions }\end{array}$ & 3.2190 & .56510 & Agree \\
2 & $\begin{array}{l}\text { Financial reports are sufficient for its purpose } \\
3\end{array} \quad \begin{array}{l}\text { Financial reports reflect true and fair view of the entity financial } \\
\text { affairs }\end{array}$ & 3.1533 & .62885 & Agree \\
4 & $\begin{array}{l}\text { The organization prepares financial statements based on } \\
\text { international and local accounting standards }\end{array}$ & 3.1387 & .50268 & Agree \\
5 & $\begin{array}{l}\text { Financial reports are worth its cost } \\
\text { Financial regulations, policy and procedures are adhered to }\end{array}$ & .56643 & Agree \\
& $\begin{array}{l}\text { ensure quality of financial reports } \\
\text { Overall Score }\end{array}$ & 3.1022 & .51855 & Agree \\
Agree
\end{tabular}

Particularly, they agreed that the management supports adoption and usage of technology, that there is availability of software and hardware at the working place, that organizational policy supports usage and adoption of technology and that management information system supports financial reporting. They also agreed that management follows up the adoption and usage of technology, that the organization provides adequate training about usage of technology and that infrastructure supports the use of technology in the organization. This suggests that the institute did well in the use of the management information system for financial reporting.

Research Question 2: What is the quality of financial reporting at the Institute of Accountancy Arusha?

This research question sought to establish the views of respondents regarding the financial reporting as described in table 2 . The table indicates that the overall mean score was 3.1375 with the standard deviation of .40669. The mean score indicates general agreement with the statements while the standard deviation shows that responses were not scattered but were close to each other.
The table further indicates that the mean score for each item was between 2.50 and 3.49 which means they agreed with all the items in table 2. This is worth noting because financial management information system is responsible for recording, analyzing, monitoring and evaluating the financial condition of organizations and providing information to support many other organizational functions (Amidu et al., 2011).

Particularly, they agreed that financial reports are relevant, comparable and reliable for decisions, that financial reports are sufficient for their purpose and that financial reports reflect true and fair view of the entity's financial affairs. They also agreed that the organization prepares financial statements based on international and local accounting standards, financial reports are worth the cost and that financial regulations, policies and procedures are adhered to in order to ensure quality of financial reports. This suggests that the institution under investigation did well in financial reporting matters.

Research Question 3: Is there significant relationship between the Management Information System and the quality of financial reporting at the Institute of Accountancy Arusha? 
The third research question was correlational in nature and therefore called for testing of the following null hypothesis: there is significant relationship between the Management Information System and the quality of financial reporting at the Institute of Accountancy Arusha.
This hypothesis was tested through the Pearson Correlations as seen in table 3 . The table presents the Sig of .000 which is lesser than the critical value and the correlation of .540 which suggests a positive and moderate relationship between the management information system and financial reporting at the Institute of Accountancy Arusha.

Table 3: Correlations between MIS and Financial Reporting

\begin{tabular}{|c|c|c|c|}
\hline & & MIS & Financial Reporting \\
\hline \multirow[t]{3}{*}{ MIS } & Pearson Correlation & 1 & $.540^{* *}$ \\
\hline & Sig. (2-tailed) & & .000 \\
\hline & $N$ & 138 & 137 \\
\hline \multirow[t]{3}{*}{ Financial Reporting } & Pearson Correlation & $.540^{* *}$ & 1 \\
\hline & Sig. (2-tailed) & .000 & \\
\hline & $N$ & 137 & 137 \\
\hline
\end{tabular}

With this background, the null hypothesis is rejected and we maintain that there is a significant relationship between the Management Information System and the quality of financial reporting at the Institute of Accountancy Arusha. Therefore, management information system affects the quality of financial reporting in a positive way.

\section{Conclusions and Recommendations Conclusions}

The study came up with the following conclusions based on the three research questions that guided the study:

Management information system operates well at the Institute of Accountancy Arusha. The institute prepares financial statements based on international and local accounting standards.

The financial reporting operates up to the required standards as indicated by the respondents who agreed that financial reports are relevant, comparable and reliable for decisions, that financial reports are sufficient for the intended purposes and that financial reports reflect true and fair view of the entity's financial affairs.

The null hypothesis whether there is a relationship between the Management Information System and the quality of financial reporting is rejected. This means the management information system affects the quality of financial reporting in a positive way. Therefore, the effective financial reporting aspect has been caused by the quality management information system.

\section{Recommendations}

The study came up with the following recommendations based on the conclusions of the study:

The institute of Accountancy Arusha should make effort to maintain the identified effectiveness of the management information system as such is very important for not only financial reporting but also for other operations in the learning institution.

The financial reporting personnel need to be appraised for their well-done job as indicated by the respondents. They need to be supplied with appropriate working environments for them to do even better in reporting financial issues in the institution.

\section{References}

Amidu,M., Effah, J. and Abor J., 2011. E accounting practices among small and medium enterprises in Ghana. Journal of Management Policy and Practice 12(4), 146-155.

CAG, 2020. Public Sector Audit for the year 2018/2019, Dodoma: National Audit Office.

Chatama Y.J., 2013. The impact of ICT on taxation: The case of large taxpayer department of Tanzania revenue authority. Developing Country Studies 3(2), 91-100. 
Kamel, M.I., Le, L.B and Girard, A, 2014. LTE wireless network virtualization: Dynamic slicing via flexible scheduling. 2014 IEEE $80^{\mathrm{TH}}$ vehicular Technology Conference. From

https://www.semanticscholar.org/pape r/LTE-Wireless-NetworkVirtualization\% 3A DynamicviaKamelLe/83f45dc4c48e9307d bceb8 0a187039300166f8d8

Kaongo, J., 2015. Assessment of Local Revenue in the Tanzania Local Government: A case ofKinondoni Municipal council. MBA Dissertation, Open University of Tanzania. From http://repository.out.ac.tz /1391 /1/Joha-DISSERTATION-24-11201 5_\% 282 \%29.pdf

Kombo,D.K. and Tromp, D.L.,, 2006. Proposal and thesis writing :An introduction. Nairobi: Paulines Publications Africa.

Mohamed, A. (2015). The international business environment: a proposed analytical framework. Int. J. Business Environment 7(2), 168-199.
Mugenda, O. \& Mugenda.A. (2003). Research methods: quantitative and qualitative methods ( $2^{\text {nd }} e d$.). Nairobi: Acts Press.

Okiro, K., Aduda, J., and Omoro, N. (2015). The effect of corporate governance and capital structure on performance of firms listed at the east african community securities exchange. European Cientific Journal 11(7), 505-533.

Renkas,J., Goncharenko, O. and Lukianets, O., 2015. Quality of financial reporting: approaches to measuring. International Journal of Accounting and Economics Studies, 4(1), pp. pp 1-5.

United Republic of Tanzania (2021). Annual General Report of the Controller and Auditor General for the Financial Year 2019/20. Dodoma, Tanzania. From https://www.nao. go.tz/ /Annual _General_Report_on_the_Audit_of_Publi c_Authorities_2019_20.pdf 